\title{
与薬業務の安全性に影響を及ぼす因子に関する研究
}

\author{
舞 床 三枝子*・菅 田 勝 也*
}

\section{Factors Effecting Medication Errors}

\author{
Mieko Maitoko* and Katsuya Kanda* \\ * Department of Fundamental Nursing, School of Health Sciences and \\ Nursing, Faculty of Medicine, University of Tokyo
}

\begin{abstract}
The purpose of this paper is to reveal factors that may occur or that may prevent medication errors, and to consider some measures of patients' safety. For this aim, we explored the characteristics of each ward and the characteristics of each nurse as well as their experiences about medication errors.

The investigation was conducted at a approximately 650 -bed university hospital located in a large urban center in Tokyo, and at a approximately 150-bed private hospital located in a suburb of Tokyo. Questionnaires were distributed in October 1991 and asked nurses to identify medication errors in which they had been personally committed within the past one-month. A response rate was approximately $70 \%$. We were informed other information of each unit from head nursessuch as the unit size, case mix, nurse staffing and working schedule of nurses.

Results indicate that on the questionnaires the nurses reported 10 times medication errors than they reported to head nurses. 56 percent of 155 nurses (except nurses who were working at an ICU and a mental ward) stated they had made medication errors or near misses during the 1-month reporting period. 30 percent of 155 stated they actually dealt with medication errors occurred by others.

Several factors that effect medication errors have been identified by a stepwise discriminant analysis. The proportion of serious patient and the bed occupancy rate influenced the occurrence of medication errors. The educational career of a nurse, especially whether the nurse had been offered an assistant nursing program or not, related to dealing with and/or preventing medication errors. Although the number of medication errors per nurse of the ICU in the university hospital was almost the same as that of the unit including ICU beds in the private hospital, but approximately 10 times more medication errors and near misses per patient were reported in the former than in the later.

Several limitations of this study dictate that the results be applied with caution. However, it may be helpful in preventing medication errors to lighten the burden of nurses, and to enlighten nurses on this subject.
\end{abstract}

要旨

看護業務の安全性を高める方策を考察する目的で, 与薬業務に焦点をあて, 与薬ミス発 生状況や確認・対処行為と, 病棟特性(業務環境) および看護婦特性との関連をみた。病床

*東京大学医学部健康科学・看護学科基礎看護学講座 
規模約650床の A 大学病院と約 150 床の B 私立病院で, 看護婦を対象にした質問紙調査を実 施した(回収率約70\%). 病棟全体の状況については婦長を対象に質問紙調査を行なった。 調査の結果, 病棟婦長が把握していない与薬ミスが相当数あることが明らかとなった。A 病院一般診療科の 155 名中 $56 \%$ が過去 1 か月間に与薬ミス・ニアミスを体験しており, 30 \%が与薬ミスに対処した経験を持っていた。与薬ミス・ニアミスの発生に対しては「看護 必要度が高い患者の割合」と「病床利用率」が影響を及ぼしていた。「看護婦の教育背景」 は, 与薬ミスの確認行為と対処行為の両者と関連があった. A 病院のICUと, B 病院のICU を含む混合病棟における与薬ミス・ニアミスは，看護婦あたりでは同程度であったが，患 者あたりでは A 病院ICUの方が多かった.

看護の質の評価については様々な研究がなさ れている.その中のひとつに，看護の質を「患 者の安全の確保」と「患者の安楽の確保」の 2 つの視点からみようとする考方方があり ${ }^{1,2}$, 看護の質の保証に拈いて両者の確保は必要不可 欠の条件である，看護婦は，患者の安全をむず 確保し，高めるよう行動しているが，その安全 さえ脅かされる場合もある. 看護婦のインシデ ントレポートで最も多いのは, 与薬業務に関す るものとされているが3)，その背後には表出し ていない数多くのミスやニアミスが存在してい ると推測されている4,5).この研究では, 与薬 業務に焦点をあて，患者の安全に影響を及ぼす 因子を「病棟の特性(看護業務環境)」と「看護 婦の特性」の側面から検討し, 看護業務の安全 性を高める方策を考察した。

\section{I ．対象と方法}

本調査実施に先だち，与薬ミスの現状につい て，看護婦(士) 30 名に聞き取り調査を行なった. 得られた情報と参考資料 6 , 7) をもとに調査票を 作成し, 病棟に配属されている看護婦 (士), 准 看護婦(士)を対象とした質問紙調査を実施した。 以降, 調査対象者を「看護職員」とょび，「看 護婦」「准看護婦」の呼称には男性も含める.

調查対象は, A大学病院 (病床数約650床, 基 準看護特 2 類)の看護職員全員(約 250 人)である. また，病院規模や与薬システムが異なる B 私立 病院 (病床数約 150 床, 基準看護特 2 類申請中) の 4 病棟のらち協力が得られた 2 病棟の看護職 員全員(約 30 人)にも同じ調査を行ない，比較検 討した。主な調査項目は, (1)過去 1 か月間の与
薬ミス・ニアミスの回数(種類別), 気付いたきっ かけ，原因と思われるもの，(2)過去 1 か月間に 与薬ミスを発見し対処した回数, 発見のきっか け，(3)過去 1 か月間に与薬ミスではないかと確 認した回数，疑問に思った理由，などである. 病棟全体の状沉については，婦長を対象とした 質問紙調査を実施した。

ここで「与薬ミス」とは，看護職員が医師の 処方とは違う与薬をすること，および医師の処 方ミスで看護職員が気付いたものをいう.「二 アミス」とは, 与薬ミスの前段階で, 間違いが, 患者の身体に影響を及ぼしていない段階をいう．

調査票は，病棟婦長を通して配布した。回収 は，A病院では「郵送による直接返送」と「病 棟婦長経由による返送」のいずれかを調査対象 者に自由に選択してもらった. B病院は, 病棟 婦長経由で回収した。調査期間は平成 3 年10月 から11月である. A 病院の回収数は, 郵送回収 54, 婦長回収132(らち無効 1 ), 回収率は約70 \%であった. 一方, B 病院の回収数は 22 であっ た.

本研究では，A病院の看護職員(婦長 8 名お よび所属病棟不明 3 名を除く) 174 名と, B 病院 のICU混合病棟看護職員(他病棟 3 名, 所属病 棟不明 6 名を除く) 13 名を分析対象とした.

\section{II. 結果}

$\mathrm{A}$ 病院の分析対象者の平均年令は29.3才で, 対象者の $64 \% か ゙ ~ 3$ 年制看護専門学校出身者であっ た. 准看護婦は $3 \%$ であった. B病院の平均年 令は 28.4 才で, 准看護婦は 3 名であった. 


\section{1. 一般診療科における与薬ミス・ニアミス}

\section{a.与薬ミス・ニアミス経験}

$\mathrm{A}$ 病院で, 与薬業務が他病棟に比べ特殊な ICU そ精神科病棟を除いた病棟(以下，「一般診療科」) の看護職員 155 名のうち, 過去 1 か月間の与薬 ミス・ニアミス経験者は 85 名 $(56 \%)$, ミス経験 者は 36 名 $(23 \%)$, 平均回数は 1.44 回 (うち, ミ ス平均回数は 0.44 回)であった.

1 か月間の与薬ミス・ニアミスの種類別頻度 を示したものが図 1 である(複数回答). 与薬ミ スで最も多かったのは「与薬遅れ」で，全体 $(67$ 回)の $28 \%$ を占める. 次いで「与薬忘れ」 $21 \%$, 「薬量違い」13\%であった。ニアミスで最も多 かったのは「与薬を忘れそらになった」で，全 体(153回)の33\%を占める．次いで「患者を間 違えそうになった」16\%，「薬の種類を間違え そらになった」 $14 \%$ ，「薬の量を間違えそらに なった」 $13 \%$ と続く.

与薬ミスやニアミスを経験した者 82 名 (詳細 無記入の 3 名を除く)に，それに気付いたさっ かけを複数回答で答えてもらったところ，「再 確認していて」が58名(71\%) と最も多かった. 次いで，「他の人に指摘されて」が36名(44\%) で，指摘した人については「患者」と回答した 者が 25 名,「看護婦」11名,「患者の家族」2名, 「医師」1名であった.「患者の状態を観察して いて」気付いた者は 3 名 $(4 \%)$ であった。 また， 与薬ミスやニアミスの原因については，「自分 の注意力や体調に問題があった」と回答した者 が 82 名のらち $82 \%$, 「病棟全体の業務量が多かっ た」44\%,「重症度や緊急度の高い患者が多かっ た」28\%であった。

\section{b .与薬ミスの発見および対処経験}

1 か月間に与薬ミスを発見し, 対処した経験 （以下，「対処経験」)がある者は47名(30\%)， 平均回数は 0.49 回であった. 種類別頻度で最も 多かったのは「点滴の滴下速度」で, 全体 (73 回)の $29 \%$, 次いで「与薬忘れ」 $25 \%$,「薬量違 い」14\%であった(表 1 ).

「対処経験」がある者 46 名(詳細無記入の 1 名を除く)に間違いに気付いたきっかけを複数 回答で答えてもらった結果, 「再確認していて」 が30名(65\%) と最も多かった．次いで「患者の 状態を観察していて」「申し送りと違っていた ので」が各 8 名 $(17 \%)$ となっていた。「他の人 に誤薬ではないかと指摘」された者は 6 名で, 指摘した人については「患者」5名，「看護婦」 1名であった。

\section{C . 与薬ミスではないかと確認する行為}

1 か月間に，与薬ミスではないかと確認した

\section{表 1 与薬ミスの対処行為, 確認行為の種類} 別頻度 (一般診療科)

\begin{tabular}{|c|c|c|}
\hline & 対処行為 & 確認行為 \\
\hline 与 薬 忘 れ & 18 (回) & 107 (回) \\
\hline 薬 量 違 い & 10 & 53 \\
\hline 患 者 違 い & 2 & 24 \\
\hline 与 薬 遅 れ & 7 & - \\
\hline 薬の種類違い & 2 & 29 \\
\hline 与薬時間違い & 5 & 17 \\
\hline 滴下速度違い & 21 & 27 \\
\hline 薬 の 重 複 & 0 & 25 \\
\hline 与薬ルート違い & 1 & 6 \\
\hline そ の 他 & 7 & 2 \\
\hline
\end{tabular}

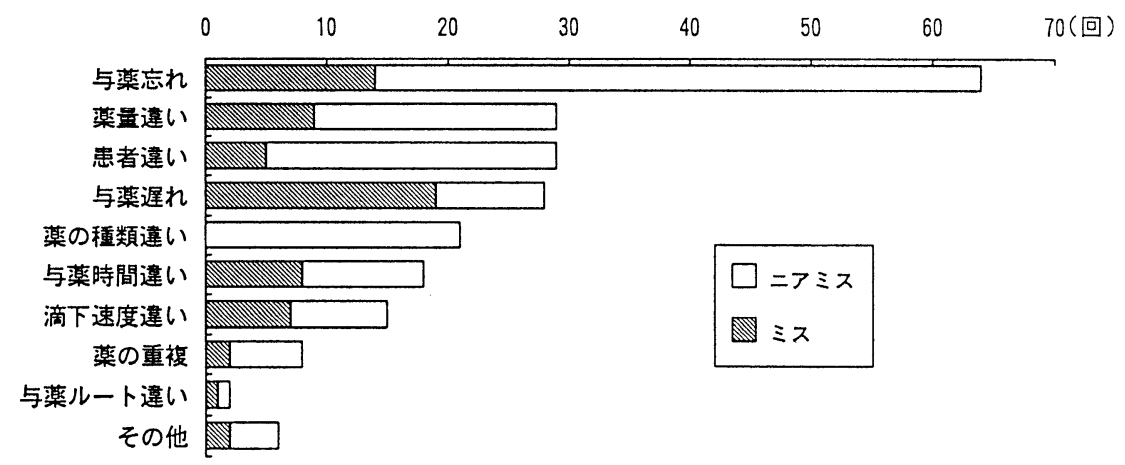

図 1 与薬に関するミス・ニアミスの種類別頻度 (一般診療科) 
経験(以下，「確認経験」)があった者は86名(55 \%)で，その延べ回数は 290 回，平均回数は 1.97 回であった．種類別頻度では多い順に「与薬 (オーダー)忘れなのではないか」37\%，「薬の 量」18\%であった(表 1 ).

「確認経験」がある者85名(詳細無記入の 1 名を除く)はそのきっかけを，「今をでの治療方 針やオーダーと違っていたので」79\%，「医学 知識や経験から判断して」32\%，「申し送りと 違っていたので」 $28 \%$ の順であげていた(複数 回答).

\section{ICUと精神科病棟における与薬ミス・ニア} ミス

$\mathrm{A}$ 病院精神科病棟 9 名の 1 か月間の与薬ミス・ ニアミス回数は看護職員 1 人あたり 0.67 回であっ た。 また $\mathrm{A}$ 病院 $\mathrm{ICU}($ 担送 4 , 配置看護職員 17 名) 10 名におけるその回数は，1 人あたり 1.70 回で, 「薬量違い」が最も多かった. B病院の ICUを含む混合病棟 (担送 31 , 護送 8 , 独歩 5 , 配置看護職員 19 名) 13 名でも 1 人あたり1.70回 で，「滴下速度違い」が最も多かった。

\section{3．与薬ミスと関連する因子 (一般診療科)}

与薬ミスやニアミスの発生状況や確認・対処 行為には，看護職員の教育背景や勤務年数など
の「看護婦特性」と, 夜勤の回数のような勤務 条件や，病床数や受け持ち患者数などの「病棟 特性」が関わっていると推察される。そこで， 看護職員および病棟の特性を規定すると考兄ら れる因子と，与薬ミス・ニアミスの発生や対処 状況，確認状況との関連を探索する目的で，A 病院一般診療科を対象に,「与薬ミス・ニアミ 又経験の有無」，「対処経験の有無」，「確認経 験の有無」を目的変数, 表 2 の11変数を説明変 数とする重判別分析を行なった．変数選択は， 「あり」「なし」の 2 つのグループ間のマハラノ ビスの平方距離が最大となる変数をステップワ イズ法 (変数追加・除去基準は候補変数の $\mathrm{F}$ 值 が $\mathrm{P}<0.1)$ で選択した。

「与薬ミス・ニアミス経験の有無」の判別に 意味があった変数は，選択された順に，看護必 要度が高い患者の割合(SEVERPT), 病棟利用 率(OCCRATE)であった。「対処経験の有無」 では，選択された順に，看護必要度が高い患者 の割合 (SEVERPT), 准看護婦教育経験の有無 (EDUCAT), 月平均勤務回数 (DUTYDAY)が, 「確認経験の有無」では, 准看護婦教育経験の 有無 (EDUCAT), 現在の病棟での勤務年数 (UNITYR)，病棟利用率 (OCCRATE) が選択さ れた(表 3 )。しかし，どの結果も誤判別率が比 較的高かった。

表 2 重判別分析に用いた変数

\begin{tabular}{|c|c|c|}
\hline & 変 & 平均値士標準偏差 \\
\hline EDUCAT & （准看護婦教育の経験の有無） & $21.9 \%^{\mathrm{a}}$ \\
\hline EXPERYR & （看護職経験年数；対数変換） & $1.33 \pm 1.21$ \\
\hline UNITYR & （現在の病棟での勤務年数；対数変換） & $0.47 \pm 0.89$ \\
\hline MEDSURG & (外科系・内科系の別) & $46.7 \%^{\mathrm{b}}$ \\
\hline $\mathrm{BED}$ & （病棟の病床数） & $45.50 \pm 11.37$ \\
\hline OCCRATE & (病床利用率 $(\%))^{\mathrm{c}}$ & $86.91 \pm 8.70$ \\
\hline PTNRS & （患者数/ 1 日の勤務看護職員数） & $3.50 \pm 0.50$ \\
\hline SEVERPT & (看護必要度が高い患者の割合 $(\%))^{d}$ & $21.56 \pm 10.28$ \\
\hline DUTYDAY & （月平均勤務回数） & $21.45 \pm 1.64$ \\
\hline EVENING & （月平均準夜回数） & $5.12 \pm 0.51$ \\
\hline MIDNIGHT & （月平均深夜回数） & $4.47 \pm 0.68$ \\
\hline
\end{tabular}

\footnotetext{
$\mathrm{a}$ ：准看護婦教育の経験 無 $=0$, 有 $=1$ (\%は有の割合)

$\mathrm{b}:$ 内科系 $=0$, 外科系 $=1$ (\%は外科系の割合)

$\mathrm{c}$ : 平成 3 年 10 月のものを適用

$\mathrm{d}$ : 看護必要度が高い患者とは，厚生省の看護度分類で $\mathrm{A}-1, \mathrm{~A}-2, \mathrm{~B}-1$ に対応する患者. 看護度別患者数は, 平成 3 年 10 月 1 日と 11 月 1 日 の平均を用いた。
} 
表 3 重判別分析結果

\begin{tabular}{|c|c|c|c|c|c|c|}
\hline & \multicolumn{2}{|c|}{ 与薬ミス・ニアミス経験の有無 } & \multicolumn{2}{|c|}{ 対処経験の有無 } & \multicolumn{2}{|c|}{ 確認経験の有無 } \\
\hline 選択順 & 数 & $\begin{array}{lrr}\text { 標 } & \text { 準 } & \text { 化 } \\
\text { 判 } & \text { 別 係 数 } \\
\end{array}$ & 変 & $\begin{array}{l}\text { 標 準 化 } \\
\text { 判 別係数 }\end{array}$ & 変 & $\begin{array}{l}\text { 標 準 化 } \\
\text { 判別係数 }\end{array}$ \\
\hline $\begin{array}{l}1 \\
2 \\
3 \\
\end{array}$ & $\begin{array}{l}\text { SEVERPT** } \\
\text { OCCRATE }^{+}\end{array}$ & $\begin{array}{l}1.015 \\
0.642\end{array}$ & $\begin{array}{l}\text { SEVERPT** } \\
\text { EDUCAT* } \\
\text { DUTYDAY* }\end{array}$ & $\begin{array}{r}-0.699 \\
-0.560 \\
0.538 \\
\end{array}$ & $\begin{array}{l}\text { EDUCAT* } \\
\text { UNITYR** } \\
\text { OCCRATE }\end{array}$ & $\begin{array}{r}-0.726 \\
0.723 \\
0.485\end{array}$ \\
\hline $\begin{array}{l}\text { 判別得点 } \\
\text { の 平 均 }\end{array}$ & $\begin{array}{l}\text { 「有」群 } \\
\text { 「無」群 }\end{array}$ & $\begin{array}{c}0.241 \\
-0.298 \\
(\mathrm{P}=0.005)^{\mathrm{a}}\end{array}$ & $\begin{array}{l}\text { 「有」群 } \\
\text { 「無」群 }\end{array}$ & $\begin{array}{c}0.493 \\
-0.229 \\
(\mathrm{P}=0.001)^{\mathrm{a}}\end{array}$ & $\begin{array}{l}\text { 「有」群 } \\
\text { 「無」群 }\end{array}$ & $\begin{array}{c}0.302 \\
-0.409 \\
(\mathrm{P}=0.001)^{\mathrm{a}}\end{array}$ \\
\hline 誤判別率 & $\begin{array}{l}\text { 「有」群 } \\
\text { 「無」群 }\end{array}$ & $\begin{array}{l}37.6 \% \\
37.7 \% \\
\end{array}$ & $\begin{array}{l}\text { 「有」群 } \\
\lceil\text { 無」群 }\end{array}$ & $\begin{array}{l}23.4 \% \\
49.5 \%\end{array}$ & $\begin{array}{l}\text { 「有」群 } \\
\text { 「無」群 }\end{array}$ & $\begin{array}{l}31.0 \% \\
32.3 \%\end{array}$ \\
\hline
\end{tabular}

$* * \mathrm{P}<0.01, * \mathrm{P}<0.05,{ }^{+} \mathrm{P}<0.1$ (追加変数の $\mathrm{F}$ 值に対する確率)

$\mathrm{a}$ マハラノビスの平方距離に対する確率

\section{4. 個人の回答傾向 (一般診療科)}

郵送回収と婦長回収に関して，有意な差がみ られた項目はなかった.「与薬ミス・ニアミス 経験の有無」と「対処経験の有無」との間の関 連はみられなかった。一方,「確認経験の有無」 と「与薬ミス・ニアミス経験の有無」,「対処 経験の有無」と「確認経験の有無」の間には, 正の関連傾向がみられた(表 4,5).

\section{5. 婦長への報告数 (一般診療科)}

$\mathrm{A}$ 病院一般診療科において, 調査前後の 2 か 月間に婦長が把握していた与薬ミスの数は, 「種類違い」 1 例, 「薬量違い」10例, 「与薬ルー

表 4 確認経験と与薬ミス・ニアミス経験と の関連

\begin{tabular}{c|c|c|c}
\hline \multirow{2}{*}{} & \multicolumn{2}{|c}{ 与薬ミス・ニアミス経験 } \\
\cline { 3 - 4 } \multicolumn{2}{c}{} & $\begin{array}{c}\text { 経験あり } \\
\text { 確 }\end{array}$ & 経験なし \\
\hline $\begin{array}{c}\text { 梙あり } \\
\text { 経 }\end{array}$ & $\begin{array}{c}31 \\
(50.8 \%)\end{array}$ & $\begin{array}{c}30 \\
(49.2 \%)\end{array}$ \\
\cline { 3 - 4 } 験 & 経験なし & $\begin{array}{c}34 \\
(39.5 \%)\end{array}$ & $\begin{array}{c}52 \\
(60.5 \%)\end{array}$ \\
\hline
\end{tabular}

表 5 対処経験と確認経験との関連

\begin{tabular}{|c|c|c|c|}
\hline & 確 誌 & 験 \\
\hline & & 経験あり & 経験なし \\
\hline \multirow{2}{*}{$\begin{array}{l}\text { 対 } \\
\text { 処 } \\
\text { 経 } \\
\text { 験 }\end{array}$} & 経験あり & $\begin{array}{c}47 \\
(47.0 \%)\end{array}$ & $\begin{array}{c}53 \\
(53.0 \%)\end{array}$ \\
\hline & 経験なし & $\begin{array}{c}15 \\
(33.3 \%)\end{array}$ & $\begin{array}{c}30 \\
(66.6 \%)\end{array}$ \\
\hline
\end{tabular}

ト違い」 1 例，「患者違い」1例であった。ま た, ニアミスについては,「薬量違い」1例で あった。

\section{III. 考察}

\section{1. 与薬ミスの発生および防止}

$\mathrm{A}$ 病院一般診療科看護職員 155 名の 1 か月間 の与薬ミス延べ回数は 67 回で, II- 5 で述べた 一般診療科の婦長が把握していた与薬ミスと対 応させてみると,「種類違い $(0$ 件 $) 」 「$ 薬量違い ( 9 件)」「与薬ルート違い ( 1 件)」「患者違い ( 5 件)」「薬の重複 ( 2 件)」「与薬忘れ (14件)」, これらカテゴリーの合計延べ数は31件であった.

一般診療科婦長の把握は上記カテゴリーに限局 されて抢り, 調査前後の 2 か月間 ( 9 月, 10月) では 1 か月平均 6.5 件であった. これは調査で 判明した数 (67回)の $9.7 \%$ で，調査法は異なる が, Francis G.の報告5) (10\%) と同程度, Ludwig らの報告7)(64\%)より少ない值であった。ただ し，Ludwig らの報告は，回答率が低い $(28 \%)$ 中での值で, バイアスがかかっている可能性が ある。

本調査では時間に関係する与薬ミスは婦長に 報告されて扔らず，時間とは関係ない上記力テ ゴリーについても，その $21 \%$ しか報告されてい ないことがわかった. 中村らの調査 ${ }^{8)}$ で, 事故 後の看護管理者の対応の仕方が報告割合と関連 することが示唆されており，看護管理者の配慮 が期待される. 


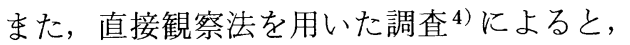
観察された与薬ミスの数は, インシデントレポー トで報告された数の 712 倍であった. 与薬ミス を看護職員が知覚できる割合, および知覚した ミスやニアミスの報告割合によって，表出する 与薬ミスの数は大きく左右されるようである.

A 病院一般診療科に括ける与薬ミスの内容に 関しては, 多い順に, (1)与薬遅れ, (2)与薬忘れ, (3)薬量違いであった. 予備調査や自由記載内容 によると,「与薬遅れ」「与薬忘れ」には, 渡し ても患者が内服していなかった場合も含まれて いた。薬を渡した後の内服確認が望まれる。

「薬量違い」については, その原因がプロセス で発生するものも多く, 処方の転記ミス, 分包 の間違いに気付かなかった, 表示と内容が違っ ていた, などがあった. 散剤や水薬では, 実際 に患者に与薬するナースが, 与薬の時点で気付 くことができなかったミスも多いと推測される. 与薬プロセス(手順)の改善が, 「薬量違い」ミ スの防止には特に有効であろう.

与薬ミス・ニアミス経験の有無と対処経験の 有無との間には関連はなかったが, 確認経験と は関連傾向がみられた。 また，対処経験を持つ 者は確認経験を持つ傾向にあった. 確認経験が あると回答した者が，与薬ミス・ニアミスの経 験も持っているといらことは，ミスしがちな看 護職員が確認をよく行ならのかもしれないが, 看護職員がミスに気付くか否かが「与薬ミス・ ニアミス経験」として表われているとも考光ら れる.このことは, 他者のミスに気付き, 対処 する傾向にある者が, 確認経験があると回答す る傾向からも示唆されている. ミスに気付かな ければ「与薬ミス・ニアミス経験」として表出 しない，与薬ミスの現状を把握するのにインシ デント・レポートがよく用いられるが, 表出し てこない与薬ミスやニアミスの存在を確認する ことも重要である。直接観察法によって「実際 に発生している与薬ミスの数」を調査し,「看 護婦が知覚できる割合」，「病棟管理者が把握 できる割合」を明らかにできれば，得やすいデー タ(インシデントレポートや質問紙調查)から患 者の安全性の確保状況が推測できる. 加えて, 与薬ミスに気付く度合いに, 教育背景による差
があるのか等も確認でき, 患者の安全性を高め るための院内教育にも役立てられると考えられ る.

本調査の調査項目と自由記載内容を照らしあ わせてみると，ミスについては記述しにくいが， 「対処経験」は書きやすく,「確認行為」は意識 化されにくい傾向が示唆されていた. 与薬ミス は与薬施行者の責によって生じるものだけでな く，与薬までのプロセスに打いて生じるものも 多い。調査対象者自身が起こした与薬ミスだけ ではなく, 対処したミスや「確認行為」によっ て防いだミスも括さえておくことは，与薬業務 の安全性の確保状況を知る上で有用であろう.

\section{2. 病棟特性や看護婦特性との関連（一般診療} 科)

$「$ 与薬ミス・ニアミス経験の有無」「対処経 験の有無」「確認経験の有無」と, 病棟特性, 看護婦特性との関連をみるために行なった判別 分析の結果では, 判別効率が良好ではなかった ので断定的にはいえないが，以下に述べる傾向 がみられた。なお判別効率が低かったのは，11 の説明変数のうち病棟特性を表わす 8 変数で, 各看護職員に同一病棟同一変数值を与えたこと が一因として考えられる.

病棟特性との関連では, 与薬ミス・ニアミス 経験の有無と看護必要度が高い患者の割合, 病 床利用率とは正の関連がみられた。このことは, 重症の患者が比較的多く入院している病棟, ま た重症患者の割合が同じとさは病床利用率が高 い病棟の方が与薬ミス・ニアミスが起こるリス クが高いことを意味している，患者の重症度が 高いと, 必然的に与薬の回数も多くなり, 与薬 業務が繁雑になることが推察される。 また, 重 症患者の割合や病床利用率は各ナースの業務量 を決定する因子であり, 業務負担の軽減も与薬 ミスのリスクを減らすのに有効であると考えら れる。

対処経験に対しては, 看護必要度が高い患者 の割合, 月平均勤務回数が影響を及ぼしていた。 看護必要度が高い患者の割合が多い病棟におけ る対処行動が少ないのは, 重症の患者はあらゆ る作用に対する抵抗力が弱いため微妙な負荷で 
も客観的変化として現われやすいので与薬施行 者自身がミスを気付きやすいため，もしくは， 重症患者の多い病棟では他者のミスをチェック 出来ないほど忙しいためと考学られるが，今回 の調査結果からはどちらともいえない。また， 勤務回数が多いと次の勤務までの間隔が離れて いないので, 患者の治療方針の把握もでき, 他 者のミスに対処できるものと考穴られる。

確認経験の有無に対しては, 病床利用率の影 響が認められた。病床利用率が高い病棟には外 科系が多く，与薬内容が頻繁に変更されるため 確認がより行われていたことが推察される。こ れらのことから, 病棟特性と与薬ミスの間には 有意な関連があり, 看護管理の重要性が確認さ れた。与薬ミスを減少させるには, 看護必要度 が高い患者の数に見合った看護要員数の確保や, 業務整理などの検討も含めて, 看護職員の業務 負担を軽減することが望をれる。

看護婦の特性との関連では, 准看護婦教育を 受けたことがないナースの方が対処経験や確認 経験を多く持っていた。これは「医師や看護婦 の指示に従う」よう教育される准看護婦教育の 性質が，ナースの自律に影響を及ぼしているも のと推察される.もしもナースの意識に問題が あるとするなら，ミス防止の役割期待に応光ら れるような院内教育も検討されるべきであろら.

また, 病棟勤務年数が長い看護職員洼ど確認行 為を行っていたことは，熟練者が新人の分まで 確認し，ミスを未然に防いでいたことがうかが える.中堅以上の看護職員の退職が患者の安全 の確保状況に及ぼす影響は大きいと推察できる.

\section{3. 病院の特性や与薬システムの影響}

$\mathrm{A}$ 病院ICUと, B 病院のICUを含む混合病棟 を比較してみると, 看護職員 1 人あたりの与薬 ミスの数, 対処回数, 確認回数には差が見られ なかったが, 患者 1 人あたりの数值でみると, $\mathrm{B}$ 病院は $\mathrm{A}$ 病院の10分の 1 である.この違いは 以下の要因によって引き起こされていると考光 られる. (1)大学病院のICUには, より重症な患 者が多く, 与薬内容が頻繁に変わる. (2)大学病 院での医師との連携の問題(䛦療科によって指 示書の書さ方が違う, 複数の医師が重複して指
示を出すことがある等). (3)処方の複雑さ; 大 学病院では薬剤の種類が多く処方が複雑である が， B病院では薬剤の基本セットを設定してお り, 種類も繁雑ではない. (4)与薬システムの違 い; B 病院では薬剤師が内服薬の分包や注射薬 剤の混合を行なっているが, $\mathrm{A}$ 病院では看護職 員が行なっている.

(4)の要因に関しては, 薬剂師による調剤の方 が実際にミスが少ないのかもしれないが，与薬 プロセスにナースが関与する機会が少なく, 調 剂ミスを発見できない可能性も否定できない。 あるいは, 調剤作業が他の業務によって中断さ れるか否かが調剤作業のミスと関連するのかも しれない，与薬ミスの発生に与薬システムがぞ ら影響するのかに関しては, 病棟および薬剂部 の実態調査による検討が必要であろう。

\section{4. 本研究の限界}

本研究の対象病院は特 2 類の基準を満たして おり, 大学附属病院といら特殊性もあることか ら,この結果を普遍的なものと考光ることは出 来ないが，与薬業務の安全性に影響を及ぼして いるものの一端が明らかにされた。過去 1 か月 間の回数を思い出してもらら形で質問紙調査を 行なったため,リコールバイアスは避けられな w.

\section{V. 結 論}

与薬ミス・ニアミスの発生や防止と看護婦特 性や病棟特性との間には関連性が認められた。 与薬ミスを減少させるには, 重症患者数に見合っ た人員配置を行うこと, および業務整理等を行 い, 看護職員の業務負担を軽減することが有効 であると考えられる，また，患者の安全性を高 めるための対処行為や確認行為は看護職員の教 育背景との関連が認められた。

稿を終えるにあたり，アンケートに御協力をい ただきました多くの方々に厚く御礼を申し上げま す.

\section{文献}

1 ) 東京看護学セミナー：安全と安楽の二視点よ 
りみた看護業務の質的評価，看護技術，17（14）, 142-159, 1971

2 ) 川島みどり：臨床における安全性と安楽性, 臨床看護, 12 (9) , 1302-1307, 1986.

3 ）小林秀代, 渡辺淳子, 俣野紀子, 横山幸子, 円谷みさ子：医療事故発生要因と多忙との関 連一事故報告書の分析から一, 第20回日本看 護学会(看護管理)集録, 257-260, 1989.

4 ) Barker K.N. and McConnell W.E.: Detecting errors in hospitals, American Journal of Hospital Pharmacy, 19, 361-369, 1962.

5 ) Francis G.: Nurses' medication “errors": a new perspective, Supervisor Nurse, 11 (8), 11-13, 1980.
$6)$ Allan E.L. and Barker K.N.: Fundamentals of medication error research, American Journal of Hospital Pharmacy , 47, 555-571, 1990.

7 ) Ludwig-Beymer P., Czurylo K.T., Gattuso M.C., Hennessy K.A. and Ryan C.J.: The effect of testing on the reported incidence of medication errors in a medical center, The Journal of Continuing Education in Nursing, 21 (1) , 11-17, 1990.

8 ）中村睦子, 石井トク, 桑名佳代子, 司関節子： 看護事故防止に関する一考察一看護管理の視 点から一，第18回日本看護学会(看護管理)集 録, 164-166, 1987. 